\title{
Interpretation of the Constitutional provisions relating to international law
}

\section{Michele Olivier*}

\section{INTRODUCTION}

The 1993 Constitution, ${ }^{1}$ for the first time in South African history accorded constitutional recognition to international law, thereby bringing an end to the debate on the status of international law in South African domestic law. This step was a symbolic break from the apartheid legal system, which was closely associated with the violation of international law and indicated to the international community that South Africa was willing to abide by internationally accepted rules. More important, however, for South African lawyers are the fundamental changes the constitutional regulation of international law introduced into South African law.

The 1993 Constitution dealt with the conclusion of international agreements (sections 82(1)(i) and 231(2)), the status of international law in South African law (section 231(3) and (4)) and the role of international law in interpreting the chapter on fundamental rights (section 35(1)). These provisions were substantially taken over by the 1996 Constitution. The provisions relating to the entry into international agreements and the status thereof in terms of South African law are once again dealt with under section 231. The provisions on customary international law are dealt with separately under section 232. Section 233 deals with the role of international law in the interpretation of legislation, whilst section 39, the equivalent of section 35 of the 1993 Constitution, provides for international law in interpreting the Bill of Rights.

Not much has yet been written as far as analysis of the above sections are concerned. Presently, the primary sources pertaining to procedural aspects are the Manual on

\footnotetext{
* This paper is based on a doctoral thesis by M E Olivier entitled International law in South African municipal law: human rights procedure, policy and practice (2002) UNISA.

1 The Interim Constitution of the Republic of South Africa, Act 200 of 1993.
} 
Executive Acts, issued by the Office of the President, and practice arising from the application of the Manual by the State Law Advisers of the Department of Foreign Affairs. Court decisions and academic writings play a very important role in decoding the relevant international law terminology used by the Constitution as well as the determination of the status various sources of international law enjoy in terms of South African law.

This paper will look at three leading court cases bearing on the constitutional status of international law:

- $\quad S v$ Makwanyane on the interpretation of section 35 of the 1993

Constitution pertaining to the role of international human rights law in the interpretation of the Bill of Rights.

- $\quad$ The judgments by the Cape High Court and the Constitutional Court in Harksen v President of the Republic of South Africa and Others on the interpretation of the term 'international agreement' as provided for by section 231 by both the 1993 and 1996 Constitutions.

\section{INTERNATIONAL LAW AS A TOOL OF INTERPRETATION: $\boldsymbol{S} V$ MAKWANYANE AND ANOTHER ${ }^{2}$}

In $S \vee$ Makwanyane and Another, the Constitutional Court dealt with the constitutionality of the death penalty. The 1993 Constitution did not express itself on the matter of capital punishment. It was decided during the negotiating process neither to exclude nor to sanction the death penalty, but to leave it to the Constitutional Court to decide whether the death penalty is consistent with Chapter 3 of the Constitution. ${ }^{3}$ The matter was brought to the Constitutional Court for decision in $S v$ Makwanyane and Another on behalf of two accused sentenced to death on counts of murder. It was contended on behalf of the accused that the imposition of the death penalty for murder was a cruel, inhuman and degrading punishment that should be declared unconstitutional. Chaskalson $P$ made extensive and creative use of international law in his judgment.

Chaskalson $\mathrm{P}$ resorted to international law in interpreting the Constitution. It was argued that documents used during the negotiating process (specifically those relating to the position of the death penalty), formed part of the context within which the Constitution should be interpreted. ${ }^{4} \mathrm{He}$ considered

\footnotetext{
2 S v Makwanyane1995 6 BCLR 665 (CC).

$3 S$ v Makwanyane1995 6 BCLR 665 (CC) par 25.

$4 S$ v Makwanyane1995 6 BCLR 665 (CC) par 12-17.
} 
circumstances existing at the time the Constitution was adopted, in interpreting the relevant provisions of the Constitution. Chaskalson found authority permitting the use of such evidence in international law. He referred to the European Court of Human Rights and the United Nations Committee on Human Rights whose deliberations are informed by traveaux preparatoires as described by article 32 of the Vienna Convention on the Law of Treaties. ${ }^{5}$ Chaskalson referred to other countries where the constitution is the supreme law such as Germany, Canada, the United States and India, where courts may have regard to circumstances prevailing during the drafting of the Constitution. ${ }^{6}$ He also makes reference to the Vienna Convention on the Law of Treaties, which may assist the court in interpretation of the Constitution. ${ }^{7}$

The second point of relevance from an international law perspective relates to the interpretation of section 35(1) of chapter 3 of the 1993 Constitution, which read as follows:

In interpreting the provisions of this Chapter a court of law shall promote the values which underlie an open and democratic society based on freedom and equality and shall, where applicable, have regard to public international law applicable to the protection of the rights entrenched in this Chapter, and may have regard to comparable foreign case law. (own emphasis)

Chaskalson underlined the distinction made by section 35 (1) between decisions of courts of foreign countries, the consideration of which is discretionary, ${ }^{8}$ and those expressions of international law which courts are obliged to consider. ${ }^{9}$ He pointed out that the court is not bound to follow either

$5 S \vee$ Makwanyane1995 6 BCLR 665 (CC) par 16 and 17. Article 32 of the Vienna Convention provides under the heading Supplementary means of interpretation: "Recourse may be had to supplementary means of interpretation, including the preparatory work of the treaty and the circumstances of its conclusion, in order to confirm the meaning resulting from the application of article 31 [general rule of interpretation], or to determine the meaning when the interpretation according to article 31; (a) leaves the meaning ambiguous or obscure; or (b) leads to a result which is manifestly absurd or unreasonable."

$6 \quad S$ v Makwanyane1995 6 BCLR 665 (CC) par 16.

7 S v Makwanyane1995 6 BCLR 665 (CC) 697 note 23.

8 N Botha "International law in the Constitutional Court" (1995) 20 SAYIL at 224 points out that under section 35 courts must consider only the international human rights law and not international law in general. He argues the decisions of foreign courts on matters of international human rights law can also be considered as peremptory but only in so far as they indirectly reflect the position under international law.

$9 \quad$ S v Makwanyane1995 6 BCLR 665 (CC) par 34. 
international law or comparable foreign case law. ${ }^{10}$ He stressed that the court must construe the South African Constitution and not an international instrument or the constitution of some foreign country and that this can only be done with due regard to South African realities. ${ }^{11}$ International agreements and international customary law provide a framework within which chapter 3 can be evaluated and understood. He proceeded to single out decisions of tribunals dealing with comparable instruments such as the United Nations Committee on Human Rights, the Inter-American Commission on Human Rights and the European Court of Human Rights, and in appropriate cases, reports of specialised agencies such as the international Labour Organisation which may provide guidance as to the correct interpretation of particular provisions of Chapter 3. ${ }^{12}$

Chaskalson interprets the term public international law as follows:

In the context of section 35(1), public international law would include non-binding as well as binding law. They may both be used under the section as tools of interpretation. ${ }^{13}$

Chaskalson describes binding law as international law binding on South Africa in terms of the requirements set out by section 231 of the Constitution. Such law would be rules of customary international law binding on South Africa and international agreements to which South Africa is a party. Non-binding international law would therefore refer to law not binding on South Africa in terms of section 231. Unfortunately Chaskalson limits such non-binding law to the traditional sources of international law as listed by section 38(1) of the Statute of the International Court of Justice. As authority Chaskalson refers to Dugard's suggestion "that section 35 requires regard to be had to 'all the sources of international law recognised by article 38(1) of the Statute of the International Court of Justice ....."14 In terms of this view non-binding sources would refer to binding international law, which do not bind South Africa

10 S v Makwanyane1995 6 BCLR 665 (CC) par 39.

$11 S$ v Makwanyane1995 6 BCLR 665 (CC) par 39.

$12 S$ v Makwanyane1995 6 BCLR 665 (CC) par 35.

$13 S$ v Makwanyane1995 6 BCLR 665 (CC) par 35.

$14 S$ v Makwanyane1995 6 BCLR 665 (CC) 686 note 46. 
namely international agreements to which South Africa is not a party, customary international law not binding on South Africa and the sources mentioned in article 38(c) and (d). The sources mentioned under article 38(c) and (d) are general principles of law recognised by civilised nations, judicial decisions and teachings of the most highly qualified publicists. ${ }^{15}$ Such interpretation excludes sources of international law falling outside the scope of article 38 such as soft law. Human rights resolutions of the United Nations General Assembly such as non-customary provisions of the Universal Declaration of Human Rights would be one very important example of an instrument of soft law, which would be excluded in terms of this interpretation.

Chaskalson concluded that "capital punishment is not prohibited by international law, and this is a factor that has to be taken into account in deciding whether it is cruel, inhuman or degrading within the meaning of section $11(2) "{ }^{16}$

Chaskalson's view that those international agreements binding on South Africa after ratification or accession in terms of article 231 provide only a framework for the interpretation of Chapter 3 under section 35, stands to be critisised. This is in contrast with the intention of the drafters that international agreements to which South Africa is a party and binding custom, should form part of the law of the land in so far as they are not in conflict with the Constitution. Surely it is necessary to differentiate on a theoretical basis between binding and non-binding international law for purposes of the interpretation of Chapter 3. Binding law is binding and non-binding is not binding but may be used for other purposes, such as an interpretative aid. It is suggested that section 35 should only refer to non-binding international law and that binding international law should be treated in terms of the provisions of section 231 .

\section{INTERPRETATION OF THE TERM INTERNATIONAL AGREEMENT BY SOUTH AFRICAN COURTS: THE HARKSEN CASES}

15 T Maluwa "The incorporation of international law and its interpretational role in municipal legal systems in Africa: an exploratory survey" (1998) 23 SAYIL at 59 argues to the contrary that there is no doubt that the scope of international law envisaged by Chaskalson $\mathrm{P}$ encompasses not only the 'hard' law of customary rules, treaty provisions and judicial decisions, but also 'soft' law contained in resolutions, declarations and guidelines drawn up by the appropriate international bodies, and also international law not binding on South Africa.

16 Section of the Constitution prohibiting cruel, inhuman or degrading treatment or punishment.. S v Makwanyane1995 6 BCLR 665 (CC) par 36. 
Where the South African Constitution of 1983 referred to "international agreements, treaties and conventions"17 both the 1993 and 1996 Constitutions speak only of an "international agreement" in their respective section 231s. Although neither of the Constitutions defines the term "international agreement", it was understood that the definition based on the Vienna Convention on the Law of Treaties would be followed which describes an international agreement as a written agreement between states governed by international law. ${ }^{18}$

Section 231 reads as follows:

1. The negotiating and signing of all international agreements is the responsibility of the national executive.

An international agreement binds the Republic only after it has been approved by resolution in both the National Assembly and the National Council of Provinces, unless it is an agreement referred to in subsection

An international agreement of a technical, administrative or executive nature, or an agreement which does not require either ratification or accession, entered into by the national executive, binds the Republic without approval by the National Assembly and the National Council of Provinces, but must be tabled in the Assembly and the Council within a reasonable time.

South African courts first entered the debate on clarifying the meaning of the term "international agreement" and the classification of different kinds of agreements for purposes of section 231 in the Harksen cases. ${ }^{19}$ The judgment of the Cape High Court $^{20}$ followed by a Constitutional Court decision $^{21}$ endorse the practical relevance of academic discourse on the meaning of the term "international agreement". The resulting constitutional interpretation provides government law advisers with much needed guidance in applying section $231 .^{22}$

17 See section 8(3)(e) of Act 110 of 1983.

18 M E Olivier "The status of international law in South African municipal law: section 231 of the 1993 Constitution" (1993/94) 19 SAYIL 5.

19 For a dicussion see N Botha "Lessons from Harksen:Constitutionality of extradition" (2000) XXXIII CILSA 274 and N Botha "International law in South African courts" (1999) 24 SAYIL 330.

20 Harksen v President of the Republic of South Africa and Others 20001 SA 1185 (CPD).

21 Harksen $v$ President of the Republic of South Africa and Others 20002 SA 825 (CC).

22 See JB Schneeberger "A labyrinth of tautology: The meaning of the term "international agreement" and its significance for South African law and treaty making practice" (2001) LLM Dissertation University of Pretoria 28. 
The facts leading to the court applications were as follows: Harksen, a German citizen present in South Africa, was sought by the Federal Republic of Germany to face charges of fraud. The South African government received a request for Harksen's extradition from Germany in March 1994. Both the South African and German governments denied the existence of an extradition treaty between them. Section 3(2) of the South African Extradition $A c t^{23}$ provides for extradition between South Africa and foreign countries where there is no extradition agreement:

\begin{abstract}
Any person accused or convicted of an extraditable offence committed within the jurisdiction of a foreign State which is not a party to an extradition agreement shall be liable to be surrendered to such foreign State, if the President has in writing consented to his or her being surrendered.
\end{abstract}

A series of diplomatic notes dealing with Harksen's extradition were exchanged by the German government and the South African government through the Department of Foreign Affairs. The president subsequently granted his consent to extradite Harksen on the basis of section 3(2) of the Extradition Act.

\title{
2. CAPE HIGH COURT APPLICATION
}

Harksen brought an application before the Cape High Court consisting of a constitutional application and a review application. The review application dealing with irregularities in the extradition inquiry will not be considered here. Of importance for present purposes is the constitutional application.

It was argued on behalf of Harksen that the President's consent in terms of section 3(2) of the Extradition Act to the German request for extradition constituted an international agreement. In fact "every extradition is regarded per se as an international agreement between the State requesting extradition and the state acceding to that request". ${ }^{24}$ Such bilateral agreement contravenes the provisions of section 231 of the Constitution which requires

23 Extradition Act 67 of 1962.

24 Harksen v President of the Republic of South Africa and Others 20001 SA 1185 (CPD) par 29. 
some form of parliamentary involvement and is therefore invalid ${ }^{25}$. Harksen inter alia relied on a supporting affidavit of Professor MG Erasmus where he stated that the "inter-State transaction" relating to Harksen's extradition indeed established a bilateral international agreement reflected in the exchange of notes. This agreement created binding rights and obligations for both states. To deny this would demonstrate an "executive-mindedness that cannot be reconciled with South Africa's new constitutional dispensation". ${ }^{26}$ It was suggested on behalf of Harksen that the Vienna Convention, specifically the definition of a treaty, forms part of South African law through section 232 of the Constitution. It was, however, submitted that the term "international agreement" is wider than the term "treaty" and would include ad hoc agreements of an informal nature. The relevance of this argument was not substantiated by indicating into which of the above categories the present series of diplomatic notes would fall. All international agreements must be dealt with under section 231(2) requiring parliamentary approval, alternatively under section 231(3) requiring tabling in parliament within a reasonable time. To become part of South African law it would have to be enacted in national legislation. Section 3(2) of the Extradition Act, which makes no provision for either parliamentary approval or tabling, would therefore be unconstitutional.

The respondents addressed two issues in their arguments namely the nature of extradition and the applicability of section 231. Regarding the first, it was suggested that in the absence of an extradition treaty, extradition is essentially an act of state based on comity between nations or the principle of reciprocity. In this regard reference was made to Botha's article "The basis of extradition: The South African perspective" 27 where he observes that a formalised strain of comity is reflected through section 3(2) of the Extradition Act. An ad hoc request for extradition and consent thereto by the President therefore does not amount to an international agreement with a status similar

25 Harksen $v$ President of the Republic of South Africa and Others 20001 SA 1185 (CPD) par 23-34.

26 Harksen $v$ President of the Republic of South Africa and Others 20001 SA 1185 (CPD) par $25 \mathrm{H}$ at 1194.

27 N Botha "The basis of extradition: the South African perspective" (1991/92) 17 SAYIL 17. 
to that of a treaty. ${ }^{28}$ Extradition in the absence of a treaty is a voluntary act, based on comity and determined by municipal law. As far as the second issue was concerned, it was argued that since there was no intention on the part of either South Africa or Germany to create an international agreement with enforceable rights and duties, the present arrangement could be regarded as an informal or ad hoc agreement or arrangement. Such instruments are legally non-binding and fall outside the scope of section $231 .^{29}$

In delivering judgment, van $\mathrm{Zyl} \mathrm{J}$ addressed the question whether the consent of the President under section 3(2) of the Extradition Act amounts to an international agreement for purposes of section 231 of the Constitution. It is heartening to find that the court did not shy away from an in-depth investigation of an international law issue. Van Zyl makes use of a wide spectrum of authority ranging from Roman law writers, internationally renowned experts on international law, to government officials to explain the meaning of an international agreement. The requirement lying at the heart of a binding international agreement is the intention of the parties to create reciprocal rights and obligations. The court stated that " it is this very intention and consent that distinguishes treaties from informal or ad hoc arrangements or agreements." ${ }^{30}$ Van Zyl proceeded to quote extensively from Baxter on the difference between "hard" and "soft" law. ${ }^{31}$ The above authority led the court to conclude that since the intention to create reciprocal rights and obligations was clearly absent in the present case, section 231 did not come into play.

Schneeberger comments on the court's decision from the perspective of the office of the SLA. As far as exchanges of notes are concerned, she alludes to the practice that the clear intention to create an international agreement should explicitly be reflected in both the note as well as the replying note. She remarks that:

28 Harksen v President of the Republic of South Africa and Others 20001 SA 1185 (CPD) par 38.

29 Harksen v President of the Republic of South Africa and Others 20001 SA 1185 (CPD) par 42.

30 Harksen v President of the Republic of South Africa and Others 20001 SA 1185 (CPD) par 52.

31 RR Baxter "International law in her infinite variety (1980) 29 ICLQ at 556. 
In addition to being used as a vehicle for the conclusion of international agreements diplomatic notes are also the bread and butter of diplomatic relations and are used on a daily basis as the standard method of diplomatic communication, Diplomatic notes would certainly make up a significant portion of what Baxter terms 'the vast sub-structure of inter-governmental paper' and if each note dealing with any matter of substance were to be considered an international agreement then it would certainly create administrative chaos ... In this sense it is a great relief that the court rejected Harksen's argument. ${ }^{32}$

The judgment can be commended for the measure of judicial clarity it provides on the meaning of the term "international agreement" in section 231. By excluding extradition under section 3(2) of the Extradition Act from the scope of section 231 , the court indirectly supported the understanding that the term "international agreements" as used by section 231 applies only to legally binding agreements creating enforceable rights and duties. ${ }^{33}$ By following this line of argument the court further recognised the separate and thriving species of informal agreements. Although they fall outside the scope of the Constitution and are not legally binding they may still bear significant legal relevance as was illustrated in the present case.

\section{THE CONSTITUTIONAL COURT APPLICATION}

The above clearly did not accord with Harksen's understanding of matters as he proceeded to approach the Constitutional Court. Harksen maintained that presidential consent under section 3(2) constituted an international agreement, which would be invalid for non-compliance with section 231 .

As in the case of the Cape High Court decision, the Constitutional Court considered the legal effect of the presidential consent under section 231. In a judgment delivered by Goldstone, the court stated that although presidential consent under section 3(2) may eventually have international resonance, the Extradition Act governs applications for extradition on the domestic plane

32 Schneeberger (2001) 33.

33 See ME Olivier "Informal international agreements under the 1996 Constitution" (1997) 22 SAYIL at 65. 
only. ${ }^{34}$ It neither initiates nor concludes extradition. ${ }^{35}$ In the light of the above the court supported the High Court decision and dismissed the submission regarding the unconstitutionality of section 3(2). Even if section 231 were to govern acts under section 3(2), failure to expressly incorporate the terms of section 231 would not render section 3(2) unconstitutional. All legislation is automatically read subject to the Constitution.

The court further disposes of the applicant's remaining submissions that presidential consent would be invalid for want of compliance with the provisions of section 231. The court accepted, with reference to Oppenheim's International Law ${ }^{36}$ that:

\begin{abstract}
Although the judicial determination of the existence of an international agreement may require the consideration of a number of complex issues, the decisive factor is said to be whether 'the instrument is intended to create international legal rights and obligations between the parties'.
\end{abstract}

The court, however, proceeded to follow a different line of reasoning than that of the Cape High Court. The latter regarded the intention of parties to create binding rights and obligations as the test for binding international agreements, however agreements between international role players not intended to create such rights and obligations were accepted as informal agreements, falling outside the scope of the Constitution. The Constitutional Court, however, maintained that there were no agreements at all in the present case, neither formal nor informal. ${ }^{37}$ The court held that the decision to extradite in terms of section 3(2) was never more than a domestic act, which was never transformed into an agreement by way of the exchange of diplomatic notes:

34 Harksen v President of the Republic of South Africa and Others 20002 SA 825 (CC) par 14.

35 Harksen v President of the Republic of South Africa and Others 20002 SA 825 (CC) par 15.

36 Harksen v President of the Republic of South Africa and Others 20002 SA 825 (CC) par 21.

37 Harksen v President of the Republic of South Africa and Others 20002 SA 825 (CC) par 21. 
In this case there is no evidence to suggest that any formal response was conveyed on behalf of South Africa to the FRG. It is thus not necessary to consider whether, if there had been such a response, an international agreement would thereby have been concluded. ${ }^{38}$

The court in effect finds that there was never any meeting of minds between the two states to extradite Harksen. The court does not address the scenario where South Africa did in fact send a diplomatic note to Germany expressing its willingness to adhere to Germany's request for extradition. It is unfortunate that the court did not express a view on the legal nature of such an agreement. In terms of this line of argument, the court pays no regard to the phenomenon of informal agreements but does not denounce their existence. The aspects of the judgment of the Cape High Court regarding informal agreements in general therefore stand.

The significance of the Constitutional Court judgment can be summarised as follows:

The first significant consequence of the Constitutional Court decision is its support for the view of the Cape High Court that international agreements for purposes of section 231 are agreements where the parties intend to create mutually enforceable rights and obligations. The meaning of the term "international agreement" as used by section 231 of the Constitution should be given a narrow interpretation to coincide with the term "treaty" as it is used in the Vienna Convention. In other words, the category of international agreements envisaged by the Constitution, refers only to legally binding agreements or treaties. Since all international agreements cannot be regarded as binding, it is implicit from the judgment that non-binding agreements between states fall outside the scope of section 231. Regrettably, the court chose not to comment on this distinction identified by the Cape High Court.

38 Harksen v President of the Republic of South Africa and Others 20002 SA 825 (CC) par 23. 
The court's view that the reason why the decision by the President in favour of extradition under section 3(2) of the Extradition Act is not an international agreement, is flawed. This decision is firstly and correctly based on the domestic nature thereof. The court however departs from this line of thinking when it argues that the facts did not indicate that the correspondence between South Africa and Germany was ever completed to formalise the matter of Harksen's extradition. The potential contradiction of the first argument lies in the fact that the court recognises the possibility that if there had been such a response, an international agreement would thereby have been concluded. ${ }^{39}$

This leads to the inevitable question as to what the legal situation would be when Germany is eventually informed of the decision to extradite Harksen. If such diplomatic correspondence (Germany's request for extradition and South Africa's communication of its decision to extradite) leads to an international agreement, the question remains whether it would be an international agreement for purposes of section 231. (The answer cannot be anything but affirmative if the existence of informal international agreements is not recognised.) If this is indeed the case, the decision by the President under section 3(2) of the Extradition Act would indeed require additional approval under section 231(2) or (3). In such a case the argument as to the domestic nature of decisions under section 3(2) goes up in smoke.

The Harksen case confronted the court with arguments where it had to search for answers in international law. Fortunately, and surprisingly, the court did not attempt to deal with this matter in terms of foreign domestic case law. The court was forced to consider the Vienna Convention in response to the applicant's arguments. Although the court was wary to accept the customary status of the Convention as a whole, it had to consult international authority such as Oppenheim and Brownlie to come to this decision.

39 Harksen v President of the Republic of South Africa and Others 20002 SA 825 (CC) par 23 at 835. 


\section{CONCLUSION}

International law, a legal system marginalized and distorted by apartheid, was restored to its rightful status as part of South African law by the 1993 and 1996 South African Constitutions. The constitutional regulation of the status of international law, however, introduced new concepts into South African law. Courts, governmental law advisers and academics are looked at to provide guidance in the interpretation of international law terminology, which have now become part of South African constitutional law. The Makwanyane and Harksen cases provide much needed guidance in this regard. In clarifying the content of the terms "public international law" in Makwanyane and "international agreement" in the Harksen cases the courts had to resort to primary sources of international law. Despite their divergent facts and legal questions, the courts in all three cases had to assess the binding nature of international law, be it as a source of international law or as legitimate species of international agreement. This requires a sound knowledge of international law. Despite the possible errors and omissions in the courts' judgments, these cases focussed the debate on the increasing relevance of international law in matters before domestic courts. 